\title{
SEASONAL AND INTRA-EVENT NUTRIENT LEVELS IN FARMED PRAIRIE POTHOLES OF THE DES MOINES LOBE
}

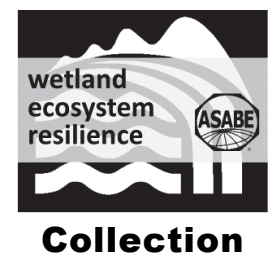

\author{
A. R. Martin, M. L. Soupir, A. L. Kaleita
}

\begin{abstract}
HighLIGHTS
- Nitrogen, total phosphorus, and total suspended solids concentrations were higher in early season inundation.

- Nitrate concentrations in farmed potholes decreased with multiday ponding.

- Farmed potholes act as hotspots, contributing P to drainage through surface intakes.
\end{abstract}

\begin{abstract}
The prairie pothole region ranges from central Iowa to the northwest into Montana and south-central Canada, totaling around $700,000 \mathrm{~km}^{2}$. This area contains millions of potholes, or enclosed topographical depressions, which often inundate with rainfall. Many are located in areas that have been converted to agricultural land through installation of artificial drainage. However, even with drainage, potholes pond or remain saturated during and after significant rain events. In this two-year study, surface water depth was collected hourly (typically from after planting through harvest) from eight farmed potholes (drained and under corn-soybean rotation) on the Des Moines Lobe in central Iowa. Nutrient data were collected daily and tested for nitrogen $(N)$ and phosphorus $(P)$ when inundation depth exceeded $10 \mathrm{~cm}$. The data were analyzed in two ways. First, seasonal differences were investigated using samples from the first day of each inundation event. Surface water concentrations were higher in the early growing season than late season for total $N(T N), N O_{3}-N, N_{3}-$ $N$, total P (TP), and total suspended solids (TSS). Secondly, average event concentration changes were determined. Nitrate reductions occurred in $85 \%$ of multiday events, but these reductions were offset by increases in $P$. Total $P$ and dissolved reactive $P(D R P)$ had significant increases that averaged 0.51 and $0.46 \mathrm{mg} \mathrm{L}^{-1}$ per event, respectively, with event lengths of 2 to 19 days. This study demonstrates that inundated farmed potholes reduce $\mathrm{NO}_{3}-\mathrm{N}$ but serve as in-field hotspots, contributing elevated TP and DRP to drainage waters. When a surface intake directly connects inundated farmed potholes to drainage, new strategies, such as field management or engineered technologies, are needed to mitigate P export. This study is useful in informing policy regarding field management and conservation of farmed potholes.
\end{abstract}

Keywords. Farmed wetland, Nitrogen, Nutrients, Phosphorus, Prairie pothole.

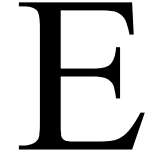

nclosed depressions that retain water for some portion of the year are common landscape features in the prairies of northern Iowa and portions of the Upper Midwestern U.S. Due to their abundance, these depressional wetlands are termed prairie potholes, and the region in which they occur is referred to as the prairie pothole region (PPR) (van der Valk, 2005). Prairie potholes are positioned in the landscape at a local minimum elevation, with small contributing areas called micro-watersheds. Prairie potholes collect

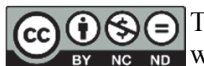

The authors have paid for open access for this article. This work is licensed under a Creative Commons AttributionNonCommercial-NoDerivatives 4.0 International License https://creative commons.org/licenses/by-nc-nd/4.0/

Submitted for review in March 2019 as manuscript number NRES 13414; approved for publication as part of the Wetland Ecosystem Resilience Collection by the Natural Resources \& Environmental Systems Community of ASABE in October 2019.

The authors are Alexander R. Martin, former Graduate Student, Michelle L. Soupir, Associate Professor, and Amy L. Kaleita, Professor, Department of Agricultural and Biosystems Engineering, Iowa State University, Ames, Iowa. Corresponding author: Michelle Soupir, 3358 Elings Hall, Iowa State University, Ames, IA 50010; phone: 515-294-2307; e-mail: msoupir@iastate.edu. and store water in response to runoff from precipitation events and from groundwater flow (Winter and Rosenberry, 1995). The Des Moines Lobe in Iowa, the focus of this study, is in the southern portion of the PPR and thus was among the first to form after the Wisconsin glacial recession 12,000 years ago (Christiansen, 1979). Based on soil mapping, the Des Moines Lobe had approximately 1.38 million ha (3.4 million acres) of land drained to prairie potholes before the implementation of artificial drainage, meaning about $44 \%$ of the total area of the lobe used to drain to prairie potholes (Miller et al., 2009).

In some instances, prairie potholes have been modified to meet the primary landscape objective to maximize agricultural production. In the past century, drainage has been widely implemented to lower the water table, improve equipment access, aerate the root zone, and increase farmable acreage. In some prairie potholes, surface inlets (or risers) are connected to subsurface drain lines to increase the drainage rate by creating a preferential path to the subsurface tile. In addition to drainage, other changes to potholes have occurred, including changing the vegetation from prairie to row crops and altering the soil structure through plowing and aeration (Streeter and Schilling, 
2015). These changes create farmed prairie potholes, which differ from undisturbed or managed prairie potholes and from traditional wetlands in several ways, including increased sedimentation and altered water chemistry compared to natural wetlands (Voldseth et al., 2007). Farmed prairie potholes are also referred to as farmed wetlands; however, because of their very different functionality, here we specifically refer to these features as farmed prairie potholes. Due to the expansion of drainage for increased agricultural production, about $53 \%$ of the pothole wetlands across the PPR have been drained, including $95 \%$ to $99 \%$ of the pothole wetlands in Iowa (Dahl, 1990).

Despite abundant research on natural wetlands and some on undisturbed prairie potholes (e.g., LaBaugh et al., 2018; Haque et al., 2018), information on farmed pothole water quality is limited. Recent work by Skopec and Evelsizer (2018) reported the average spring surface water nutrient concentrations from 16 sites with farmed potholes. Concentrations were higher in farmed potholes than in natural prairie wetlands or restored prairie wetlands that are part of the Wetland Reserve Program, with significant intra- and interannual variability at the farmed potholes. The groundwater beneath farmed potholes had mean concentrations of 16.7 and $0.4 \mathrm{mg} \mathrm{L}^{-1}$ of nitrate $\left(\mathrm{NO}_{3}-\mathrm{N}\right)$ and dissolved reactive phosphate (DRP), respectively, which were similar to subsurface tile drainage concentrations in central Iowa (Schilling et al., 2018). Nitrate concentrations were impacted by climate fluctuations, with lower concentrations in 2012 during dry conditions and higher concentrations in 2013 when heavy precipitation saturated the system.

Sediment transfer is also a concern with drainage. Runoff displaces soil and transports it to lower elevations. Erosion causes depressions to slowly fill over time. Surface inlets create a location for preferential flow to streams that is not filtered by buffers or soil (Blann et al., 2009), allowing the sediment in runoff to leave the field rather than settle. Sediment in drainage causes concerns for its effects on suspended solids in streams and because phosphorus is sorbed to it (Smith and Livingston, 2013). Surface inlets in the Tipton Creek watershed in Iowa accounted for $13 \%$ of flow (Tomer et al., 2010), while a study in the Southern Minnesota River basin had an average of $5 \%$ of its annual flow and up to $138 \mathrm{~kg} \mathrm{ha}^{-1}$ of solids attributed to surface inlets (Ginting et al., 2000). The combination of excess nitrogen (N) and phosphorus $(\mathrm{P})$ from drainage has led to increased algae blooms in water bodies downstream of agricultural lands.

Traditional wetland systems have shown a wide range of contaminant concentration reductions, including $\mathrm{N}, \mathrm{P}$, and suspended solids (Hammer, 1992). Nitrogen removal occurs mostly through denitrification by bacteria, although wetland vegetation takes up small amounts of $\mathrm{N}$ as well (Woltemade, 2000). Inundation of wetlands is important, as it creates the anaerobic conditions needed for denitrification (Dinnes et al., 2002). Other requirements for denitrification include dissolved organic carbon and an $\mathrm{N}$ source. However, even when these two requirements are met, denitrification is low in farmed potholes due to systematic differences, including low water tables and increased aerobic conditions from drainage (and thus short periods of inundation) (Schilling et al., 2018). In traditional wetlands, P removal occurs in several ways.
Because $\mathrm{P}$ is usually adsorbed to soil particles, much removal comes from sedimentation of particles as the water slows or stops within wetlands. Additional removal occurs due to adsorption, complexation, and precipitation within wetlands (Woltemade, 2000). However, drained potholes have also been reported to be a source of $\mathrm{P}$, while undisturbed wetlands are more likely to be a sink for P (Badiou et al., 2018). The repeated wetting and drying of drained potholes causes organic $\mathrm{P}$ to convert to bioavailable $\mathrm{P}$ during aerobic conditions, while iron reduction releases $\mathrm{P}$ during anoxic conditions (Aldous et al., 2005; Badiou et al., 2018). The released $\mathrm{P}$ is then exported in drainage water.

This study addresses temporal differences in the surface water quality of farmed prairie potholes and the potential nutrient loads that are associated with artificial drainage of that water. The goal of this study was to investigate surface water quality in farmed potholes in the Des Moines Lobe. The objectives were to: (1) compare growing season concentrations in the surface water quality of farmed potholes, (2) determine water quality trends throughout an inundation event, and (3) describe the potential nutrient loads due to surface drainage in farmed potholes. Findings from this work have the potential to inform management of farmed potholes. For example, if $\mathrm{P}$ and total suspended solids (TSS) levels are elevated, the presence of a surface intake provides preferential pathways for export to tile drain lines. This information is needed for government agencies and agricultural groups to understand the impact and make decisions regarding farmed prairie pothole management.

\section{Methods}

\section{SITE DESCRIPTION}

Potholes were monitored at two field sites for this study. One site $\left(41^{\circ} 58^{\prime} 59^{\prime \prime} \mathrm{N}, 93^{\circ} 41^{\prime} 17^{\prime \prime} \mathrm{W}\right)$ is located southwest of Ames, Iowa, along the border of the Walnut and Worrell Creek HUC-12 watersheds in Story County. This site contains seven farmed potholes, which were named for their unique shapes and proximity to other potholes (Lettuce, Bunny, Walnut, Gravy, Turkey, Potatoes, and Yam) (fig. 1), and is farmed in a corn-soybean rotation. The secondary site $\left(42.015^{\circ} \mathrm{N}, 93.743^{\circ} \mathrm{W}\right)$ is west of Ames in the Worrell Creek HUC-12 watershed of Boone County. It contains a retired prairie pothole (Mouth) that is part of the Conservation Reserve Program (CRP). The two sites are located approximately $5.6 \mathrm{~km}$ (3.5 mi) apart and are both at farms operated by the Agricultural Engineering/Agronomy and Central Iowa Research Farms of Iowa State University. Seven of the potholes (Bunny, Lettuce, Gravy, Walnut, Turkey, Potatoes, and Mouth) were sampled in 2016 and 2017. The eighth pothole (Yam) was only sampled in 2017 because it was added as an additional monitoring location when significant flooding was observed during a heavy rainfall event in the fall of 2016. The inclusion of Yam proved important due to its tendency to flood, even in dry years. In 2017, more than twothirds of the total samples for the year were collected from Yam.

Pothole areas and volumes were derived using high-reso- 


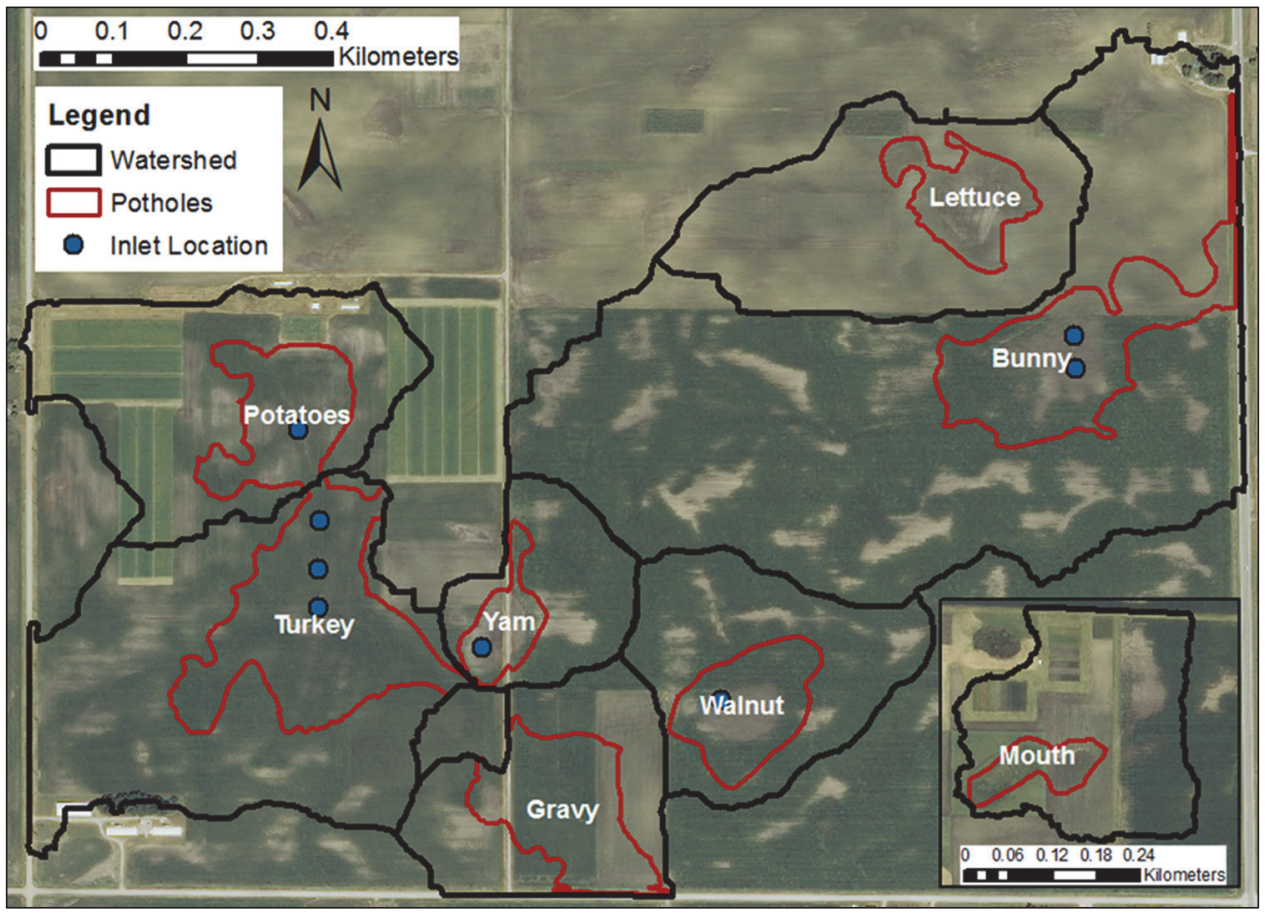

Figure 1. Pothole locations and names with micro-watershed and pothole delineation. Inset shows the second site with its retired pothole and corresponding micro-watershed.

Table 1. Summary of pothole characteristics derived using LiDAR.

\begin{tabular}{ccccc}
\hline & $\begin{array}{c}\text { Pothole } \\
\text { Area } \\
\text { (ha) }\end{array}$ & $\begin{array}{c}\text { Micro- } \\
\text { Watershed } \\
\text { Area } \\
(\text { ha) }\end{array}$ & $\begin{array}{c}\text { Maximum } \\
\text { Depth } \\
(\mathrm{m})\end{array}$ & $\begin{array}{c}\text { Maximum } \\
\text { Volume } \\
\left(\mathrm{m}^{3}\right)\end{array}$ \\
\hline Pothole & 5.35 & 41.1 & 1.0 & 29,400 \\
Bunny & 3.60 & 8.7 & 0.7 & 5,900 \\
Lettuce & 2.11 & 12.7 & 0.8 & 8,300 \\
Mouth & 0.94 & 8.4 & 0.3 & 1,100 \\
Potatoes & 2.96 & 13.0 & 0.5 & 4,100 \\
Turkey & 6.60 & 20.8 & 0.6 & 15,400 \\
Walnut & 2.60 & 9.8 & 0.8 & 11,800 \\
Yam & 1.20 & 5.4 & 0.8 & 3,800 \\
\hline
\end{tabular}

lution elevation data from LiDAR, which allows better determination of the size and shape of potholes that are often less than a meter deep (table 1). The LiDAR-based digital elevation raster data were obtained from the Iowa LiDAR Project (https://geodata.iowa.gov/dataset/iowa-lidar-project-2007-2010) based on data collected from 2007 to 2010. Previously, hydric soils, such as the Okoboji soil series, have been used to delineate pothole areas (NRCS, 1998). However, soil mapping inaccuracies led to hydric soils extending outside of the elevation boundaries of the potholes, while some depressions in this study had inundation but were not mapped as hydric soils. Depth to surface area and volume relationships were derived in ArcMap 10.2 (ESRI, 2013) and are described in detail by Martin et al. (2019). Surface area and volume were calculated at $10 \mathrm{~cm}$ depth intervals, and a combination of second-order equations and linear interpolation was applied to each pothole.

A majority of the land use was row crops, rotating between corn and soybeans (table 2). Two potholes had an access road through them: one road running through the middle of Yam, and another road near the edge of Gravy (fig. 1). Additionally, Turkey and Potatoes had Miscanthus plots in
Table 2. Summary of pothole vegetation and drainage. Drainage with surface inlets also has subsurface drainage.

\begin{tabular}{ccc}
\hline Pothole & Vegetation $(2016-2017)$ & Drainage \\
\hline Bunny & Soybean/corn $(\mathrm{S} / \mathrm{C})$ & Two surface inlets \\
Gravy & $\mathrm{S} / \mathrm{C}$ & Subsurface only \\
Lettuce & $\mathrm{C} / \mathrm{S}$ & Subsurface only \\
Mouth & Retired (surrounded by C/S) & No drainage (assumed) \\
Potatoes & $\mathrm{S} / \mathrm{C}$ & Surface inlet \\
Turkey & $\mathrm{S} / \mathrm{C}$ & Three surface inlets \\
Walnut & $\mathrm{S} / \mathrm{C}$ & Surface inlet \\
Yam & $\mathrm{S} / \mathrm{C}$ and grass & Surface inlet \\
\hline
\end{tabular}

their micro-watersheds during 2016, although these were removed and returned to row crops in 2017. Because Yam had ponded water during planting in 2017 , it was planted to grass at the end of June. Mouth was on retired land, with most of its micro-watershed in row crops and some Miscanthus plots in the northern part of the micro-watershed.

Fertilization depended on the crop, as it is only applied in the year corn was planted. Both potassium $(\mathrm{K})$ and $\mathrm{P}$ fertilizers were applied variably based on gridded soil tests, with up to $260 \mathrm{lb}^{\mathrm{bcre}}{ }^{-1}$ of potash and $220 \mathrm{lb}$ acre $^{-1}$ of monoammonium phosphate. These fertilizers were applied in the fall after soybean harvest. Nitrogen was applied pre-plant with side dressing as needed, totaling $140 \mathrm{lb} \mathrm{N}$ acre ${ }^{-1}$ as urea and ammonium nitrate. Fertilization rates were within the usual application levels, which was important when considering their potential effects on water quality. Because Mouth was on retired land, there was no direct fertilization of the pothole, but there was fertilization in the micro-watershed surrounding the pothole.

\section{FIELD AND LABORATORY METHODS}

Each pothole was monitored for inundation depth hourly using a pressure transducer (Solinst Levelogger). Each sen- 
sor was corrected against a centrally located pressure transducer to account for barometric pressure, with an additional correction made to adjust for the known sensor depth underground. Monitoring started when the first crop was planted during early to mid-May and lasted until harvest during the middle to end of October. Pre-planting inundation depth observations were not collected due to the logistics of field instrumentation.

Daily samples of $1 \mathrm{~L}$ were collected when pothole inundation exceeded $10 \mathrm{~cm}$ (4 in.). Excessive resuspension of sediment occurred when inundation was less than $10 \mathrm{~cm}$; because of this, two early samples were disregarded. The first sample was collected within $24 \mathrm{~h}$ of the start of the inundation event. The sampling regime did not allow assessment of first-flush water quality dynamics, which have been reported to occur within the first hours of inundation (Jones et al., 2015). Sample collection typically occurred after crop planting, but in three cases when inundation occurred prior to planting and the field sites were accessible, samples were collected before planting. For the three samples collected prior to planting, water elevation was collected using GPS. However, because inundation only occurred for a single day, the samples were only used in the seasonal (first day only) sample analysis described below. All samples were stored and transported on ice to the water quality research laboratory at Iowa State University. The samples were split, with one portion receiving sulfuric acid to reduce the $\mathrm{pH}$ to $<2$ for preservation, before being stored at $4^{\circ} \mathrm{C}$ until analysis.

The samples were analyzed for six nutrients: dissolved reactive phosphorus as $\mathrm{P}$ (DRP), total phosphorus as $\mathrm{P}$ (TP), total suspended solids (TSS), ammonia as $\mathrm{N}\left(\mathrm{NH}_{3}-\mathrm{N}\right)$, nitrate plus nitrite as $\mathrm{N}\left(\mathrm{NO}_{3}-\mathrm{N}\right)$, and total nitrogen as $\mathrm{N}(\mathrm{TN})$. The unadjusted sample was used for DRP and TSS analysis, while the acidified portion was used for $\mathrm{TP}, \mathrm{NH}_{3}-\mathrm{N}, \mathrm{NO}_{3}-\mathrm{N}$, and TN analysis. DRP was tested by filtering $20 \mathrm{~mL}$ through a $0.45 \mu \mathrm{m}$ filter and then using Method EPA-118-A Rev 5 on a Seal Analytical AQ2 discrete analyzer. TSS was tested using Standard Method 2540-D (Rice and Bridgewater, 2012). TP was tested using Method EPA-119-A Rev 6 on the AQ2 discrete analyzer. $\mathrm{NH}_{3}-\mathrm{N}$ was tested using Method EPA-103-A Rev 10. $\mathrm{NO}_{3}-\mathrm{N}$ analysis varied depending on the concentration: Method EPA-114-A Rev 7 was used first with the AQ2 discrete analyzer, and then Method EPA-126A Rev 7 was used for samples with less than $0.25 \mathrm{mg} \mathrm{N} \mathrm{L}^{-1}$. Similarly, TN analysis used two methods: Hach Method 10071 (Hach, 2014a) was used first, and then Hach Method 10072 (Hach, 2014b) was used for concentrations exceeding $25.0 \mathrm{mg} \mathrm{N} \mathrm{L}^{-1}$.

\section{DRAINAGE ESTIMATES}

Assessing the water balance of a farmed pothole is complex because of the omnidirectional flow into the pothole as well as the presence of subsurface drainage with or without surface intakes. Surface drainage estimates were used to calculate the nutrient load export from the potholes. Surface drainage for Bunny and Walnut was estimated as part of a water balance that included direct rainfall, runoff and interflow, evapotranspiration, infiltration, and surface drainage, and details are available in our companion article (Martin et al., 2019). Briefly, daily water fluxes were determined and
Table 3. Maximum surface drainage rates $\left(\mathrm{m}^{3} \mathrm{~h}^{-1}\right)$ for Bunny and Walnut based on depth.

\begin{tabular}{ccc}
\hline $\begin{array}{l}\text { Inundation } \\
\text { Depth }(\mathrm{m})\end{array}$ & Bunny & Walnut \\
\hline$<0.03$ & 0 & 0 \\
\hline 0.03 to 0.05 & $1933 \times\left(h_{t}-0.03\right)^{1.5}$ & 0 \\
\hline 0.05 to 0.07 & $1933 \times\left(h_{t}-0.03\right)^{1.5}$ & $-0.705 \times\left(h_{t}-0.05\right)^{3}$ \\
& & $+15.46 \times\left(h_{t}-0.05\right)^{2}$ \\
& & $+24.33 \times\left(h_{t}-0.05\right)$ \\
\hline 0.07 to 0.32 & $13.16 \times\left[19.62 \times\left(h_{t}-0.03\right)\right]^{0.5}$ & $-0.705 \times\left(h_{t}-0.05\right)^{3}$ \\
& & $+15.46 \times\left(h_{t}-0.05\right)^{2}$ \\
& & $+24.33 \times\left(h_{t}-0.05\right)$ \\
\hline$>0.32$ & $13.16 \times\left[19.62 \times\left(h_{t}-0.03\right)\right]^{0.5}$ & $-0.705 \times\left(h_{t}-0.05\right)^{3}$ \\
& $+16.2 \times\left[19.62 \times\left(h_{t}-0.32\right)\right]^{0.5}$ & $+15.46 \times\left(h_{t}-0.05\right)^{2}$ \\
& & $+24.33 \times\left(h_{t}-0.05\right)$ \\
\hline
\end{tabular}

adjusted for evapotranspiration and direct rainfall. Days with runoff and interflow were excluded, leaving daily water fluxes that only included infiltration and surface drainage. Hydraulic conductivity (for infiltration) and a drainage efficiency coefficient were adjusted at each pothole until the estimated drainage and infiltration best matched the measured values.

One challenge in estimating the water balance was the condition of the inlet risers. Bunny had two surface inlets with risers (fig. 1). The north riser was knocked over, likely by agricultural machinery, leaving a $10 \mathrm{~cm}$ diameter hole for surface drainage that was $3 \mathrm{~cm}$ above the bottom of the pothole. The inlet was assumed to behave as weir flow (eq. 1) until ponded water was $4 \mathrm{~cm}$ above the inlet and as a horizontal orifice at deeper levels (eq. 2), which follows work by Roth and Capel (2012):

$$
\begin{gathered}
Q_{d}=C_{w} \pi d h_{t}^{1.5} \\
Q_{d}=C_{o} a \sqrt{2 g h_{t}}
\end{gathered}
$$

where

$Q_{d}=$ drainage flow into surface drain $\left(\mathrm{m}^{3} \mathrm{~h}^{-1}\right)$

$C_{w}=$ weir coefficient $\left(1.71 \mathrm{~m}^{0.5} \mathrm{~s}^{-1}\right)$

$d=$ diameter of surface drain $(\mathrm{m})$

$h_{t}=$ water depth above drain $(\mathrm{m})$

$C_{o}=$ orifice coefficient $(0.60)$

$a=$ area of surface drain opening $\left(\mathrm{m}^{2}\right)$

$g=$ gravitational acceleration $\left(9.81 \mathrm{~m} \mathrm{~s}^{-2}\right)$.

The inlet was determined to have a drainage efficiency of 0.77 , and the reduction in efficiency was assumed to be caused by sediment blockage. The south riser was also damaged and did not have an opening until $32 \mathrm{~cm}$ above the bottom of the pothole. Orifice flow was assumed for the $75 \mathrm{~cm}^{2}$ opening. Walnut had improvements to the tile drainage in fall 2015, resulting in increased subsurface drainage and a $20 \mathrm{~cm}$ diameter riser on the surface inlet. A drainage curve was determined using manufacturer specifications (table 3 ). Because the manufacturer specification assumed 50\% blockage, a drainage efficiency of 1.16 was used to better fit the actual drainage rate. The inlet was $5 \mathrm{~cm}$ above the bottom of the pothole.

\section{Data AnAlysis}

Seasonal trends were determined using the first sample of each event. An event was defined as the inundation period 
that occurred in response to a precipitation event. Samples collected on subsequent days were not used for this analysis because they were time-dependent and did not fit the conditions of independences required for the statistical assessment. Non-normally distributed samples were natural logarithm transformed. Samples were split between early season (May and June) and late season (July through October) in relation to plant growth. The middle of the growing season (July and August) was not included because of insufficient sample numbers.

Event trends were evaluated for the change in mean daily concentration. Samples were grouped by land cover (soybean, corn, or retired), inundation day, or season (early or late). For all groups, the average daily change was temporally independent of events because the daily change was averaged over multiple events in each group. For inundation day, the day-to-day changes were grouped from 1 to 5 (for the number of days after the initial sample) and averaged over multiple events. Similar analysis was conducted to assess change over an entire event. The groups were tested individually for having a mean change greater than zero using one-sided t-tests $(\alpha=0.05)$. Groups that did not have a significant mean change greater than zero were also tested for having a mean change less than zero.

Event pollutant load estimations were made by multiplying the surface drainage estimates and the daily water quality concentrations. Some drainage occurred on days at the start or end of inundation events in which the $10 \mathrm{~cm}$ depth criterion was not met, and thus a sample was not collected. In these cases, the concentration from the nearest day was used, with no sample extended more than one day. Similarly, during some smaller events, inundation and drainage occurred but samples were not collected, and thus loads were not calculated.

\section{RESULTS AND DISCUSSION}

\section{SAMPLE SUMMARY}

A total of 144 samples were collected from eight potholes. Thirty of those samples were collected on the first day of inundation. A sample was also considered to be the first day if $>90 \%$ of the ponded water was attributable to additional rainfall that occurred between the daily samples. For example, one period of inundation lasted for 37 days; however, within that period, two additional rainfall events occurred that met the criterion that $90 \%$ of the ponded water was attributable to the additional rainfall. Therefore, within the 37-day period, three first-day samples were collected, and the greatest period of inundation was 18 days.

The pothole water quality data were similar to previously reported values for farmed potholes (table 4). Skopec and Evelsizer (2018) reported spring nutrient levels $\left(\mathrm{NO}_{3}-\mathrm{N}\right.$, $\mathrm{NH}_{3}-\mathrm{N}, \mathrm{TP}$, and DRP) for 16 sites in the Des Moines Lobe based on one sample per farmed pothole during pre-planting, planting, and post-planting periods (from April to June). They did not specify the sample timing within an event, as the purpose of their study was a population analysis of concentrations during the spring. This implies that the best comparison is to the range, mean, and median of early-season
Table 4. Mean, median, and range of concentrations for all surface water samples compared to the values for drained, Wetland Reserve Program (WRP), and reference wetlands reported by Skopec and Evelsizer (2018). "Farmed" includes soybean and corn crops.

\begin{tabular}{lllllll}
\hline & \multicolumn{5}{c}{ Nutrient Concentration $\left(\mathrm{mg} \mathrm{L}^{-1}\right)$} \\
\cline { 2 - 7 } & $\mathrm{TN}$ & $\mathrm{NO}_{3}-\mathrm{N}$ & $\mathrm{NH}_{3}-\mathrm{N}$ & $\mathrm{TP}$ & DRP & TSS \\
\hline
\end{tabular}

\begin{tabular}{|c|c|c|c|c|c|c|}
\hline \multicolumn{7}{|l|}{ This study } \\
\hline \multicolumn{7}{|c|}{ Farmed, early season $(n=31)$} \\
\hline Mean & 19.37 & 14.85 & 0.53 & 0.73 & 0.37 & 240.5 \\
\hline Median & 19.58 & 15.12 & 0.11 & 0.48 & 0.31 & 74.0 \\
\hline Max. & 40.71 & 39.73 & 5.91 & 2.74 & 1.12 & 3400.0 \\
\hline Min. & 7.82 & 0.88 & $<0.02$ & 0.13 & 0.06 & 2.3 \\
\hline \multicolumn{7}{|c|}{ Farmed, late season $(n=73)$} \\
\hline Mean & 2.49 & 0.26 & 0.07 & 0.76 & 0.62 & 81.4 \\
\hline Median & 2.10 & $<0.03$ & $<0.02$ & 0.60 & 0.43 & 24.0 \\
\hline Max. & 9.52 & 5.38 & 0.88 & 1.75 & 1.66 & 1392.0 \\
\hline Min. & 0.22 & $<0.03$ & $<0.02$ & 0.11 & $<0.02$ & 1.0 \\
\hline \multicolumn{7}{|c|}{ Retired, early season $(n=12)$} \\
\hline Mean & 2.30 & 0.10 & 0.14 & 0.88 & 0.71 & 55.4 \\
\hline Median & 2.33 & $<0.03$ & 0.09 & 0.80 & 0.67 & 24.1 \\
\hline Max. & 4.21 & 1.79 & 0.50 & 1.95 & 1.33 & 850.0 \\
\hline Min. & 0.96 & $<0.03$ & $<0.02$ & 0.45 & 0.31 & 7.0 \\
\hline \multicolumn{7}{|c|}{ Retired, late season $(n=28)$} \\
\hline Mean & 2.95 & 0.73 & 0.05 & 0.17 & 0.05 & 16.9 \\
\hline Median & 2.88 & 0.39 & 0.04 & 0.15 & 0.03 & 16.5 \\
\hline Max. & 4.42 & 2.51 & 0.10 & 0.40 & 0.18 & 49.2 \\
\hline Min. & 1.91 & $<0.03$ & 0.03 & 0.07 & 0.02 & 4.0 \\
\hline \multicolumn{7}{|c|}{ Skopec and Evelsizer (2018) } \\
\hline \multicolumn{7}{|c|}{ Drained $(n=144)$} \\
\hline Mean & - & 11.6 & 3.18 & 1.95 & 1.09 & - \\
\hline Median & - & 1 & 0.1 & 1.2 & 0.62 & - \\
\hline Max. & - & 610 & 290 & 31 & 27 & - \\
\hline Min. & - & $<0.1$ & $<0.05$ & 0.11 & $<0.02$ & - \\
\hline \multicolumn{7}{|c|}{$\overline{\mathrm{WRP}(n=69)}$} \\
\hline Mean & - & 0.72 & 0.09 & 0.39 & 0.17 & - \\
\hline Median & - & 0.05 & 0.05 & 0.23 & 0.05 & - \\
\hline \multicolumn{7}{|c|}{ Reference $(n=12)$} \\
\hline Mean & - & 0.05 & 0.06 & 0.2 & 0.09 & - \\
\hline Median & - & 0.05 & 0.05 & 0.14 & 0.04 & - \\
\hline
\end{tabular}

concentrations (May and June) of the farmed potholes in our study. However, Skopec and Evelsizer (2018) presented the only other published dataset of surface water concentrations in farmed potholes. Minimum concentrations were similar in both studies and were at or near the reporting limit for the respective tests. However, the maximum concentrations were about one order of magnitude less in our study than the values reported by Skopec and Evelsizer (e.g., $39.7 \mathrm{mg} \mathrm{L}^{-1}$ compared to $610 \mathrm{mg} \mathrm{L}^{-1}$ for $\mathrm{NO}_{3}-\mathrm{N}$ ). Mean and median concentrations were similar in our study, while mean and median concentrations for $\mathrm{NO}_{3}-\mathrm{N}$ and $\mathrm{NH}_{3}-\mathrm{N}$ were skewed by an order of magnitude in Skopec and Evelsizer (2018).

The comparable means and medians and the lack of high maximums in our study were likely due to similar practices across the farmed potholes, with each having a corn-soybean rotation with $140 \mathrm{lb} \mathrm{N}$ acre $^{-1}$ applied as urea and ammonium nitrate prior to corn planting. While Skopec and Evelsizer (2018) did not specify crop types or fertilization rates, it is likely that their 16 sites varied in management and included at least one site in continuous corn, as about $33 \%$ of the cropland in Iowa consists of continuous corn (Tomer et al., 2017). Continuous corn has higher $\mathrm{N}$ fertilization rates (Sawyer, 2018), which lead to higher N levels in ponded water. Schilling et al. (2018) reported groundwater nutrient concentrations at eight sites in the Des Moines Lobe. In their 
study, $\mathrm{NO}_{3}-\mathrm{N}$ and DRP had means of 16.76 and $0.36 \mathrm{mg}$ $\mathrm{L}^{-1}$, respectively, which were similar to the surface water means in our study. Overall, the surface water concentrations in our study were within the ranges in the population analysis reported by Skopec and Evelsizer (2018) and were similar to the farmed pothole groundwater averages reported by Schilling et al. (2018).

\section{EARLY AND Late Growing SEASON DifFerences}

Nutrient concentrations were compared between the early and late growing season for the first-day samples from the farmed potholes (table 5). TN ( $\mathrm{p}<0.0001), \mathrm{NO}_{3}-\mathrm{N}(\mathrm{p}<$ $0.0001), \mathrm{NH}_{3}-\mathrm{N}(\mathrm{p}=0.005), \mathrm{TP}(\mathrm{p}=0.036)$, and TSS $(\mathrm{p}=$ 0.028 ) were all significantly lower in the late season than in the early season, while DRP was not. Total $\mathrm{N}$, which ranged from 7.82 to $40.71 \mathrm{mg} \mathrm{L}^{-1}$ in the early season, was lower in the late season, with a range of 1.50 to $8.28 \mathrm{mg} \mathrm{L}^{-1}$ (fig. 2). Similarly, $\mathrm{NO}_{3}-\mathrm{N}$ ranged from 4.46 to $39.73 \mathrm{mg} \mathrm{L}^{-1}$ in the early season and from $<0.03$ to $5.38 \mathrm{mg} \mathrm{L}^{-1}$ in the late season. $\mathrm{NH}_{3}-\mathrm{N}$ concentrations were $>0.10 \mathrm{mg} \mathrm{L}^{-1}$ for $55 \%$ of the

Table 5. Nutrient mean concentrations $\left(\mathrm{mg} \mathrm{L}^{-1}\right)$ of first-day samples for the early and late growing season with different types of land cover. "Farmed" includes soybean and corn crops. For the farmed potholes, different letters indicate significantly different concentrations between early season and late season. Not enough samples were collected from the retired pothole for a similar statistical comparison.

\begin{tabular}{cccccc}
\hline & \multicolumn{2}{c}{ Farmed } & & \multicolumn{2}{c}{ Retired } \\
\cline { 2 - 3 } \cline { 5 - 6 } & $\begin{array}{c}\text { Early } \\
\text { Season } \\
(n=11)\end{array}$ & $\begin{array}{c}\text { Late } \\
\text { Season } \\
(n=13)\end{array}$ & & $\begin{array}{c}\text { Early } \\
\text { Season } \\
(n=2)\end{array}$ & $\begin{array}{c}\text { Late } \\
\text { Season } \\
(n=4)\end{array}$ \\
\hline $\mathrm{TN}$ & $21.10 \mathrm{a}$ & $3.34 \mathrm{~b}$ & & 3.07 & 2.34 \\
$\mathrm{NO}_{3}-\mathrm{N}$ & $15.32 \mathrm{a}$ & $0.68 \mathrm{~b}$ & & 0.12 & 0.58 \\
$\mathrm{NH}_{3}-\mathrm{N}$ & $0.36 \mathrm{a}$ & $0.05 \mathrm{~b}$ & & 0.04 & 0.07 \\
$\mathrm{TP}$ & $1.05 \mathrm{a}$ & $0.62 \mathrm{~b}$ & & 0.28 & 0.60 \\
$\mathrm{DRP}$ & $0.40 \mathrm{a}$ & $0.43 \mathrm{a}$ & & 0.10 & 0.42 \\
$\mathrm{TSS}$ & $546 \mathrm{a}$ & $134 \mathrm{~b}$ & & 35 & 238 \\
\hline
\end{tabular}
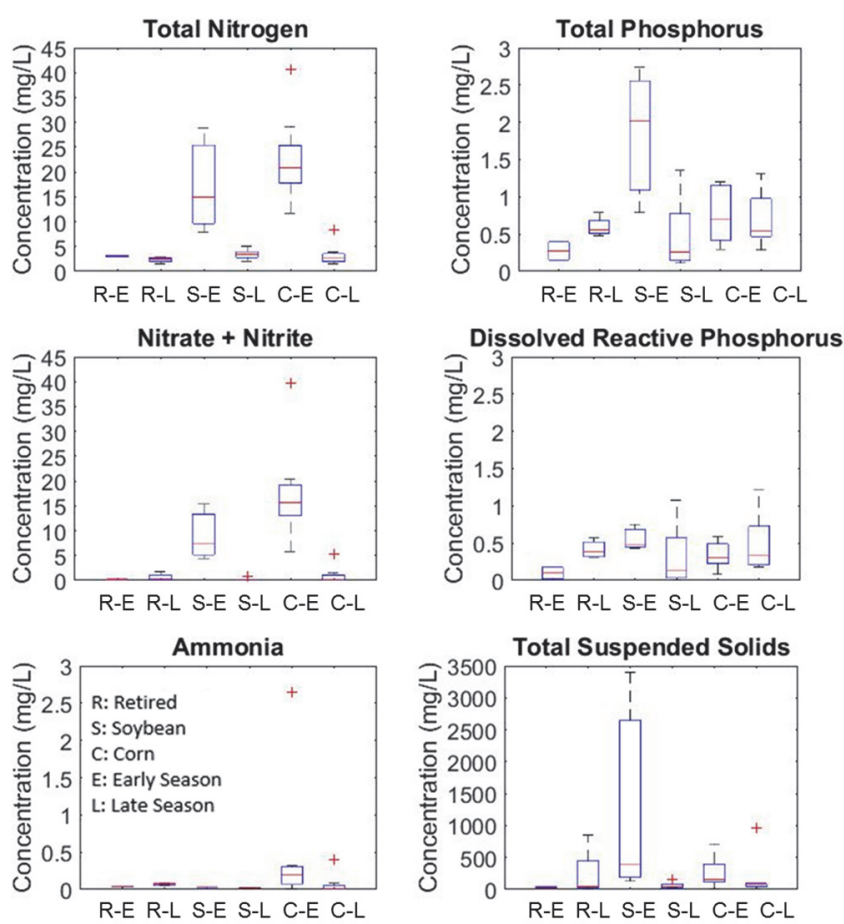

Figure 2. Boxplots of nutrient concentrations of the first sample for each event by land cover $(R=$ retired, $S=$ soybean, and $C=$ corn $)$ and season $(E=$ early and $L=$ late $)$. early season, while $92 \%$ of late-season samples were $<0.10 \mathrm{mg} \mathrm{L}^{-1}$. Early-season TP concentrations ranged from 0.30 to $2.74 \mathrm{~m} \mathrm{~L}^{-1}$, while late-season TP concentrations ranged from 0.11 to $1.35 \mathrm{mg} \mathrm{L}^{-1}$. Concentrations of TSS were $>100 \mathrm{mg} \mathrm{L}^{-1}$ for $82 \%$ of the early season, while $85 \%$ of late-season samples were $<100 \mathrm{mg} \mathrm{L}^{-1}$. DRP had similar ranges for both seasons.

The retired pothole samples tended to have lower concentrations in the early season compared to the late season, but there were insufficient samples for statistical analysis. Earlyseason mean concentrations for all nutrients were lower when the pothole had CRP cover compared to crop cover, while late-season concentrations were similar. The retired pothole also had little temporal change in TSS concentrations between seasons with no samples greater than $60 \mathrm{mg}$ $\mathrm{L}^{-1}$, except for one sample that had a TSS concentration of $850 \mathrm{mg} \mathrm{L}^{-1}$ due to large pieces of suspended, woody biomass rather than sediment. While the data were insufficient for statistical tests comparing the farmed and retired potholes, grassland reduces suspended sediments when used as a filter strip and would likely have similar benefits in potholes (Gharabaghi et al., 2006; Pan et al., 2010).

Nitrogen-based nutrients were higher in the early season, likely due to fertilization occurring shortly before planting corn crops and organic matter decay from the previous year's crop (Chen et al., 2014). Because nitrate is mobile, it was flushed with interflow during precipitation events and transported to the farmed potholes (Zhu et al., 2009). While $\mathrm{P}$ is less soluble than nitrate and binds to soil particles (Kowalenko, 2005), TP was still significantly different between seasons. Higher early-season TP concentrations were potentially related to TSS, as TSS had elevated concentrations in the early season when the soil was bare and the erosion potential was higher. Warmer temperatures in the late season might have led to additional $\mathrm{P}$ release from saturated soil (Holdren and Armstrong, 1980; Koerselman et al., 1993). The DRP:TP ratio was 0.63 for first-day samples in the late season and only 0.44 in the early season.

\section{EVENT TRENDS}

Table 6 presents the mean daily concentration changes for land cover, day of inundation, and season for multiple events. For the land cover and season groups, the average daily change was temporally independent of events. For example, if 15 daily changes were recorded that were related to four separate events, table 6 reports the average of the 15 daily changes. The mean daily concentration change was significantly positive (increase) for DRP $(p<0.0001)$ and TP $(p<0.0001)$ regardless of land cover, day of inundation, and season. Only $\mathrm{NO}_{3}-\mathrm{N}(\mathrm{p}=0.0499)$ had a significant negative mean daily change (decrease) when all daily changes were considered, although a significant decrease in $\mathrm{NO}_{3}-\mathrm{N}$ was only observed in the late growing season. $\mathrm{TN}, \mathrm{NH}_{3}-\mathrm{N}$, and TSS did not have significant increases or decreases in mean daily concentration change. DRP had significant increases with time for most groups, including all three land covers (soybean, corn, and retired), the first four days of inundation, and both growing seasons (early and late). TP followed a similar pattern, largely due to the influence of increasing DRP concentrations, as it had significant increases 
Table 6. Mean daily change $\left(\mathrm{mg} \mathrm{L}^{-1}\right)$ in concentration for different groups of land cover, day of inundation, and season. For land cover and season, the mean daily change in concentration is the average of the daily change that occurred independent of event timing. Change between sample days is the daily change within the inundation period. Asterisks (*) denote significant changes.

\begin{tabular}{|c|c|c|c|c|c|c|c|}
\hline & & $\mathrm{TN}$ & $\mathrm{NO}_{3}-\mathrm{N}$ & $\mathrm{NH}_{3}-\mathrm{N}$ & $\mathrm{TP}$ & DRP & TSS \\
\hline \multirow[t]{3}{*}{ Land cover } & Soybean & -0.02 & -0.05 & 0.00 & $0.16^{*}$ & $0.15^{*}$ & 7 \\
\hline & Corn & -0.33 & -0.37 & 0.04 & $0.07 *$ & $0.07 *$ & 8 \\
\hline & Retired & 0.02 & -0.07 & 0.02 & $0.08 *$ & $0.08 *$ & -25 \\
\hline \multirow{5}{*}{$\begin{array}{c}\text { Change between } \\
\text { sample days }\end{array}$} & Days 1-2 & -0.92 & -0.12 & 0.13 & 0.03 & $0.09 *$ & -112 \\
\hline & Days 2-3 & -0.16 & -0.14 & -0.05 & $0.15^{*}$ & $0.17 *$ & 27 \\
\hline & Days 3-4 & 0.75 & 0.14 & 0.01 & $0.14 *$ & $0.07 *$ & 19 \\
\hline & Days 4-5 & -0.53 & -0.74 & 0.04 & $0.09 *$ & $0.08^{*}$ & 5 \\
\hline & Days 5-6 & 0.04 & -0.46 & -0.01 & $0.12 *$ & 0.05 & 23 \\
\hline \multirow[t]{2}{*}{ Season } & Early & -0.78 & -0.70 & 0.06 & 0.04 & $0.04 *$ & -8 \\
\hline & Late & 0.05 & $-0.08^{*}$ & 0.02 & $0.11 *$ & $0.09 *$ & 0 \\
\hline All & & -0.18 & $-0.24 *$ & 0.03 & $0.09 *$ & $0.08^{*}$ & -2 \\
\hline
\end{tabular}

for all three land covers, the second through fifth day of inundation, and the late season. TSS was expected to decrease significantly, but the results were inconclusive because the concentrations were highly variable (mean daily change of $-2 \mathrm{mg} \mathrm{L}^{-1}$ with a standard deviation of $188 \mathrm{mg} \mathrm{L}^{-1}$ ).

Overall, the mean event change in concentration was similar to the daily changes, with a significant concentration increase for DRP and TP and a decrease for $\mathrm{NO}_{3}-\mathrm{N}$ (table 7). There were significant increases in DRP and TP for most event groups. DRP and TP both had $90 \%$ of the 20 multiday events end with higher concentrations than on the first day. $\mathrm{NO}_{3}-\mathrm{N}$ had a significant decrease only for late-season events $(p=0.006)$ despite $85 \%$ of all events having lower concentrations by the last day, only one event having an increase in concentration, and two events remaining below the detection limit throughout the event. $\mathrm{NO}_{3}-\mathrm{N}$ reduction in the potholes was likely due to denitrification. Denitrification was not measured but was assumed to be the primary $\mathrm{NO}_{3}-\mathrm{N}$ removal mechanism, given the well documented process in the wetlands literature (Bartlett et al., 1979; Gale et al., 1993; Phipps and Crumpton, 1994). While not significant, tables 6 and 7 show positive changes in mean daily and mean event $\mathrm{NH}_{3}-\mathrm{N}$ concentrations. This could indicate that dissimilatory reduction of nitrate to ammonia or ammonium (DNRA) is another potential mechanism of $\mathrm{NO}_{3}-\mathrm{N}$ removal.

In three of the four early-season events in corn, reductions of more than $7.40 \mathrm{mg} \mathrm{NO}_{3}-\mathrm{N} \mathrm{L}^{-1}$ were observed over varying event lengths. However, we observed an increase of $9.74 \mathrm{mg}$ $\mathrm{L}^{-1}$ during a four-day event. This event occurred after the first significant rainfall following fertilizer application. This trend was also observed in other events that occurred soon after fertilizer application, but those events lasted longer than ten days and had reductions by the end. Nitrate increases are likely caused by additional nitrate entering via interflow (Zhu et al., 2009), as additional interflow can enter a pothole for up to six days after a rainfall event (Martin et al., 2019). It is expected that the $\mathrm{NO}_{3}-\mathrm{N}$ concentration would have been lower by the end of this event had nitrate from the recent fertilization not entered with interflow. While $\mathrm{NO}_{3}-\mathrm{N}$ concentrations decreased more on average for early-season events $\left(4.20 \mathrm{mg} \mathrm{L}^{-1}\right.$ reduction) than for late-season events (0.44 $\mathrm{mg} \mathrm{L}^{-1}$ reduction), the early-season concentrations were not found to decrease significantly because of a larger standard deviation $\left(9.06 \mathrm{mg} \mathrm{L}^{-1}\right)$ than the late season (0.58 $\left.\mathrm{mg} \mathrm{L}^{-1}\right)$.

Unlike nitrate, $\mathrm{P}$ concentrations increased during events, largely due to increases in DRP. The mean DRP concentration for all events was $0.40 \mathrm{mg} \mathrm{L}^{-1}$ on the first day, and multiday events had an average event increase of $0.46 \mathrm{mg} \mathrm{L}^{-1}$ (115\%). The mean TP concentration increase was $0.51 \mathrm{mg}$ $\mathrm{L}^{-1}$, meaning that about $90 \%$ of the increase was attributable to the DRP increase. Due to large DRP increases, the average DRP:TP ratio increased from 0.52 to 0.70 between the first and last days of events. Concentrations did not increase at a consistent rate, as shown in figure 3.

Temporal changes in DRP varied throughout the events, with increases occurring either within a few days of inundation (Mouth or Bunny after September 23, fig. 3) or later in the inundation period (Lettuce after September 28, fig. 3). Concentration decreases were also observed during rainfall events (Lettuce on September 23, fig. 3), as the previous surface water became diluted with new influxes. The increases in DRP and TP concentrations were likely due to the repeated wetting and drying during inundation events and sediment resuspension. Multiple studies have shown that dried sediments have increased $\mathrm{P}$ release when wetted, compared to areas that remain inundated, which includes wetting and drying in drained wetlands (Kröger et al., 2012; DeLonge et al., 2013; Badiou et al., 2018). In wetlands, iron reduction during saturated conditions and increased mineralization of organic $\mathrm{P}$ during dry conditions are both likely causes for $\mathrm{P}$ release (Aldous et al., 2005; Loeb et al., 2008). Resuspension of sediments also leads to increased concentrations of TP and DRP. Sediments in farmed potholes can be resuspended by wind and release DRP, as reported previously for shallow lakes (Kristensen et al., 1992; Sondergaard et al., 1992). Because farmed potholes are shallower than lakes and often have no land cover before crop emergence or due to crop

Table 7. Mean event change $\left(\mathrm{mg} \mathrm{L}^{-1}\right)$ for different groups of land cover and season. Asterisks (*) denote significant changes.

\begin{tabular}{cccccccc}
\hline & & $\mathrm{TN}$ & $\mathrm{NO}_{3}-\mathrm{N}$ & $\mathrm{NH}_{3}-\mathrm{N}$ & $\mathrm{TP}$ & $\mathrm{DRP}$ & $\mathrm{TSS}$ \\
\hline Land cover & Soybean & -0.08 & -0.27 & 0.00 & 0.79 & 0.75 & 37 \\
& Corn & -1.77 & -2.02 & 0.22 & $0.42^{*}$ & $0.36^{*}$ & 39 \\
& Retired & 0.11 & -0.50 & 0.13 & $0.56^{*}$ & $0.51^{*}$ & -168 \\
\hline \multirow{2}{*}{ Season } & Early & -4.67 & -4.20 & 0.38 & 0.21 & 0.22 & -48 \\
& Late & 0.16 & $-0.44^{*}$ & 0.09 & $0.61^{*}$ & $0.54^{*}$ & -1 \\
\hline All & & -1.05 & -1.38 & 0.16 & $0.51^{*}$ & $0.46^{*}$ & -13 \\
\hline
\end{tabular}




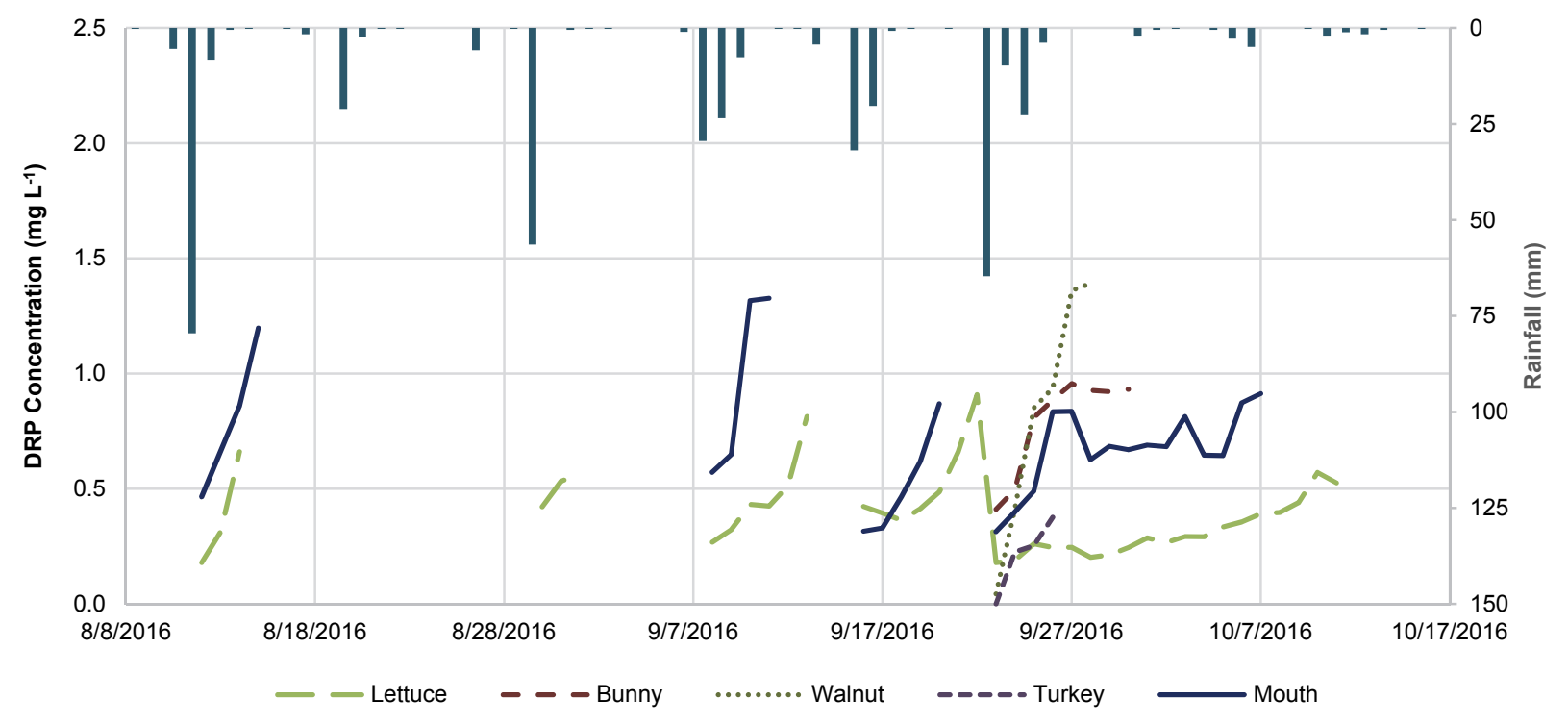

Figure 3. Increase in DRP concentrations during events in the late season of 2016.

drowning, wind variance is a likely cause of day-to-day sediment variance, and this explains why the reported TSS concentrations were variable in this study (standard deviation of $\left.188 \mathrm{mg} \mathrm{L}^{-1}\right)$. Additionally, TP concentrations had a larger range of daily change $\left(-0.37\right.$ to $\left.0.98 \mathrm{mg} \mathrm{L}^{-1}\right)$ than DRP $(-0.21$ to $\left.0.67 \mathrm{mg} \mathrm{L}^{-1}\right)$. The difference between these ranges is likely due to unreactive $\mathrm{P}$ bound to sediments.

\section{Pollutant Surface Load Estimation}

Cumulative and unit-area loads exiting the potholes through surface inlets were estimated for each of the six water quality parameters at Bunny and Walnut, as those two potholes had significant surface inundation and thus drainage through surface inlets (table 8). Additional load export occurred through infiltration, which was calculated. However, possible interactions in the soil, such as denitrification and settling, would have changed the concentrations before pollutants entered the subsurface drainage, and thus only loads exported through the surface inlets are reported. By calculating the load export through surface intakes, the reduction potentially achievable through mitigation efforts can be quantified and assessed relative to other water quality practices. Loads were only calculated for Bunny in 2016, as there was no notable inundation during 2017. Surface drainage in Walnut mostly occurred during the fall of 2016, with one event in early 2017. Samples were collected for $97 \%$ of the estimated drainage, with inundation occurring in both potholes, but a sample was not collected if the pothole drained before sampling could occur. The cumulative loads for both potholes were within the same order of magnitude (table 8). At Bunny, most of the cumulative load occurred during a late-season inundation event that accounted for nearly all of the drainage that was sampled. A small event in the early season was sampled and had an estimated $0.03 \%$ of the total surface drainage. This event accounted for $4 \%$ of the $\mathrm{NO}_{3}-\mathrm{N}$ load and $6 \%$ of the TSS load, although it did not significantly affect the other pollutant loads. Similarly, the small, early-season event in 2017 at Walnut only had 1\% of the total drainage but had increased load impact per volume drained for $\mathrm{TN}, \mathrm{NO}_{3}-\mathrm{N}, \mathrm{NH}_{3}-\mathrm{N}$, and TSS.

The N-based loads were low compared to a previous assessment of $\mathrm{NO}_{3}-\mathrm{N}$ loads in runoff by Tomer et al. (2016), who reported loads ranging from 0.76 to $0.89 \mathrm{~kg} \mathrm{ha}^{-1} \mathrm{year}^{-1}$. This is expected, as much of the drainage in this study occurred during the late season, when $\mathrm{TN}, \mathrm{NO}_{3}-\mathrm{N}$, and $\mathrm{NH}_{3}-\mathrm{N}$ concentrations were significantly lower than in the early season. This study also only calculated loads from planting until harvest, missing preplanting loads that carried spring fertilizer application. Early-season concentrations of $\mathrm{NO}_{3}-\mathrm{N}$ were three orders of magnitude larger than during the late season, while TN concentrations were one order of magnitude larger. Overall, the $\mathrm{NO}_{3}-\mathrm{N}$ load was only about $5 \%$ of the TN load, but $\mathrm{NO}_{3}-\mathrm{N}$ was the dominant component of early-season TN loads, comprising nearly $80 \%$ of the load. Because both years were unusually dry for much of the early season, $\mathrm{NO}_{3}-\mathrm{N}$ loads are expected to be larger in years of average spring rains, resulting in greater TN loads as well. For example, if the large drainage event from the late season occurred instead during the early season, the surface inlet load at Walnut would have been larger for that one event.

Table 8. Estimated loads at Bunny and Walnut farmed potholes due to surface inlet drainage. Bunny only includes data from 2016 as there was no inundation in 2017.

\begin{tabular}{|c|c|c|c|c|c|c|c|c|}
\hline & & $\mathrm{TN}$ & $\mathrm{NO}_{3}-\mathrm{N}$ & $\mathrm{NH}_{3}-\mathrm{N}$ & $\mathrm{TP}$ & DRP & TSS & Water $\left(\mathrm{m}^{3}\right)$ \\
\hline \multirow[t]{2}{*}{ Bunny } & Load $(\mathrm{kg})$ & 29.4 & 1.21 & 0.064 & 8.85 & 7.35 & 155 & 9733 \\
\hline & Area-weighted load $\left(\mathrm{kg} \mathrm{ha}^{-1}\right)$ & 0.91 & 0.038 & 0.002 & 0.27 & 0.23 & 5 & 302 \\
\hline \multirow[t]{4}{*}{ Walnut } & Load $(\mathrm{kg})$ & 5.66 & 0.30 & 0.024 & 1.44 & 1.21 & 261 & 1920 \\
\hline & Area-weighted load $\left(\mathrm{kg} \mathrm{ha}^{-1}\right)$ & 0.58 & 0.031 & 0.002 & 0.15 & 0.12 & 27 & 196 \\
\hline & $2016(\%)$ & 0.94 & 0.12 & 0.81 & 0.99 & 0.99 & 0.98 & 0.99 \\
\hline & $2017(\%)$ & 0.06 & 0.88 & 0.19 & 0.01 & 0.01 & 0.02 & 0.01 \\
\hline
\end{tabular}


Phosphorus and sediment loads were similar compared to other studies, with the largest unit-area loads being $0.27 \mathrm{~kg}$ $\mathrm{ha}^{-1}$ (TP at Bunny), $0.23 \mathrm{~kg} \mathrm{ha}^{-1}$ (DRP at Bunny), and $27 \mathrm{~kg}$ $\mathrm{ha}^{-1}$ (TSS at Walnut) in 2016. While these values are a little lower than the average TP runoff loads of 1.0 to $1.8 \mathrm{~kg} \mathrm{ha}^{-1}$ year $^{-1}$ reported by Tomer et al. (2016), both years in this study had dry conditions in June and July, with reduced runoff, and this study only captured the period from planting until harvest. In 2016, surface loads from three subwatersheds near Blackhawk Lake, about $140 \mathrm{~km}(90 \mathrm{mi})$ distant from this study, were $<0.01$ to $0.35 \mathrm{~kg} \mathrm{ha}^{-1}$ (TP), $<0.001$ to $0.054 \mathrm{~kg} \mathrm{ha}^{-1}$ (DRP), and $<1$ to $200 \mathrm{~kg} \mathrm{ha}^{-1}$ (TSS) (Brendel, 2017). The TP and TSS unit-area loads at Bunny and Walnut in 2016 were within this range, but DRP unit-area loads were higher than at Blackhawk Lake. The increased DRP loads from potholes came from $P$ released during extended inundation, which would not occur in other surface runoff loads.

These surface load calculations are only a fraction of the total pollutant load leaving farmed potholes, as subsurface drainage would also contribute to the overall load. The infiltration estimates in this study only included surface water that leaves the potholes through subsurface drainage, while subsurface drainage would remove additional groundwater both during and between inundation events. While the unit load from surface drainage is similar to other surface runoff studies, the load from a pothole is in addition to baseline conditions; in a natural system, the water would remain in the pothole for a longer period. Across the Des Moines Lobe, about $44 \%$ of the land drains to potholes, and $95 \%$ to $99 \%$ of the potholes in Iowa are drained (Miller et al., 2009; Johnson et al., 2008), which indicates that these distributed water quality hotspots have a potentially significant impact on downstream water quality.

\section{Conclusions}

Surface water quality samples were collected from eight potholes, typically after planting through harvest, during a two-year study and tested for $\mathrm{TN}, \mathrm{NO}_{3}-\mathrm{N}, \mathrm{NH}_{3}-\mathrm{N}, \mathrm{TP}, \mathrm{DRP}$, and TSS. Most of the nutrients had higher concentrations in the early growing season compared to the late season, with likely causes being fertilizer application and lack of land cover. $\mathrm{NO}_{3}-\mathrm{N}$ reduction was common in the potholes, occurring during $85 \%$ of the multiday events, but the water quality benefits due to nitrate reduction during inundation coincided with TP and DRP increases. Pollutant loads into the surface inlets were estimated for two potholes, which had unit-area loads similar to runoff loads in the region for 2016 despite the shortened timeframe. Overall, the surface water quality was directly impacted by the agricultural production occurring in the farmed potholes through decreased land cover, fertilizer addition, and connecting water with elevated P levels directly to subsurface drainage through surface intakes. Future work is recommended to expand the sampling timeframe to include preplanting for a more comprehensive assessment of nutrient export from potholes, and to monitor the subsurface drainage water quality below the potholes.

This study informs stakeholders about current water quality conditions in these farmed potholes and should help guide future research and policy regarding potential solutions to reduce nutrient loads. For example, better understanding of nutrient export from potholes will inform strategies for meeting nutrient reduction strategies. Regarding $\mathrm{NO}_{3}-\mathrm{N}$ export, these results suggest that inundation provides some nitrate removal and thus farmed potholes could perhaps be managed as water quality treatment zones instead of areas of low-quality crop production. Supporting the need for this strategy is the finding that inundated farmed potholes are in-field hotspots, contributing TP and DRP to drainage water. When a surface intake directly connects inundated farmed potholes to drainage, there are opportunities to implement new strategies through changes in field management or engineered technologies, such as using the standpipe as a treatment zone to mitigate $\mathrm{P}$ export. In the Des Moines Lobe region of Iowa, approximately $44 \%$ of the land drains to potholes, and $95 \%$ to $99 \%$ of the potholes in Iowa are drained. Thus, farmed potholes serve as both hotspots for $\mathrm{P}$ export to drainage and an opportunity for targeted mitigation. Finally, by targeting in-field nutrient export hotspots for mitigation, we can invest conservation funds in a more effective manner.

\section{ACKNOWLEDGEMENTS}

Funding was provided by the Leopold Center for Sustainable Agriculture and the U.S. Environmental Protection Agency (EPA). Although the research described here has been funded wholly or in part by the U.S. EPA under assistance agreement CD97753901 to Iowa State University, it has not been subjected to the EPA's product and administrative review and therefore might not necessarily reflect the views of the EPA; no official endorsement should be inferred. The authors would like to thank Leigh Ann Long for water quality analysis.

\section{REFERENCES}

Aldous, A., McCormick, P., Ferguson, C., Graham, S., \& Craft, C. (2005). Hydrologic regime controls soil phosphorus fluxes in restoration and undisturbed wetlands. Restor. Ecol., 13(2), 341347. https://doi.org/10.1111/j.1526-100X.2005.00043.x

Badiou, P., Page, B., \& Akinremi, W. (2018). Phosphorus retention in intact and drained prairie wetland basins: Implications for nutrient export. J. Environ. Qual., 47(4), 902-913. https://doi.org/10.2134/jeq2017.08.0336

Bartlett, M. S., Brown, L. C., Hanes, N. B., \& Nickerson, N. H. (1979). Denitrification in freshwater wetland soil. J. Environ. Qual., 8(4), 460-464. https://doi.org/10.2134/jeq1979.00472425000800040004x

Blann, K. L., Anderson, J. L., Sands, G. R., \& Vondracek, B. (2009). Effects of agricultural drainage on aquatic ecosystems: A review. Crit. Rev. Environ. Sci. Tech., 39(11), 909-1001. https://doi.org/10.1080/10643380801977966

Brendel, C. (2017). Evaluation of subsurface drainage on phosphorus losses and application of the SoillceDB model in the Black Hawk Lake watershed, Iowa. MS thesis. Ames, IA: Iowa State University, Department of Agricultural and Biosystems Engineering.

Chen, B. Q., Liu, E. K., Tian, Q. Z., Yan, C. R., \& Zhang, Y. Q. (2014). Soil nitrogen dynamics and crop residues. A review. Agron. Sustain. Devel., 34(2), 429-442.

https://doi.org/10.1007/s13593-014-0207-8 
Christiansen, E. A. (1979). The Wisconsinan deglaciation of southern Saskatchewan and adjacent areas. Canadian J. Earth Sci., 16(4), 913-938. https://doi.org/10.1139/e79-079

Dahl, T. E. (1990). Wetlands losses in the United States, 1780s to 1980s. Report to Congress. Washington, DC: U.S. Fish and Wildlife Service.

DeLonge, M., Vandecar, K. L., D’Odorico, P., \& Lawrence, D. (2013). The impact of changing moisture conditions on shortterm P availability in weathered soils. Plant Soil, 365(1-2), 201209. https://doi.org/10.1007/s11104-012-1373-6

Dinnes, D. L., Karlen, D. L., Jaynes, D. B., Kaspar, T. C., Hatfield, J. L., Colvin, T. S., \& Cambardella, C. A. (2002). Nitrogen management strategies to reduce nitrate leaching in tile-drained midwestern soils. Agron. J., 94(1), 153-171. https://doi.org/10.2134/agronj2002.1530

Gale, P. M., Devai, I., Reddy, K. R., \& Graetz, D. A. (1993). Denitrification potential of soils from constructed and natural wetlands. Ecol. Eng., 2(2), 119-130. https://doi.org/10.1016/0925-8574(93)90034-D

Gharabaghi, B., Rudra, R. P., \& Goel, P. K. (2006). Effectiveness of vegetative filter strips in removal of sediments from overland flow. Water Qual. Res. J., 41(3), 275-282. https://doi.org/10.2166/wqrj.2006.031

Ginting, D., Moncrief, J. F., \& Gupta, S. C. (2000). Runoff, solids, and contaminant losses into surface tile inlets draining lacustrine depressions. J. Environ. Qual., 29(2), 551-560. https://doi.org/10.2134/jeq2000.00472425002900020024x

Hach. (2014a). Method 10071: Nitrogen, total, Test 'N Tube. TNT persulfate digestion method $(0.5$ to $25.0 \mathrm{mg} / \mathrm{L} \mathrm{N})$. Loveland, CO: Hach Company

Hach. (2014b). Method 10072: Nitrogen, total, Test 'N Tube. TNT persulfate digestion method ( 2 to $150 \mathrm{mg} / \mathrm{L} \mathrm{N}$ ). Loveland, CO: Hach Company

Hammer, D. A. (1992). Designing constructed wetlands systems to treat agricultural nonpoint-source pollution. Ecol. Eng., 1(1-2), 49-82. https://doi.org/10.1016/0925-8574(92)90025-W

Haque, A., Ali, G., Macrae, M., Badiou, P., \& Lobb, D. (2018). Hydroclimatic influences and physiographic controls on phosphorus dynamics in prairie pothole wetlands. Sci. Total Environ., 645, 1410-1424. https://doi.org/10.1016/j.scitotenv.2018.07.170

Holdren, G. C., \& Armstrong, D. E. (1980). Factors affecting phosphorus release from intact lake sediment cores. Environ. Sci. Tech., 14(1), 79-87. https://doi.org/10.1021/es60161a014

Johnson, R. R., Oslund, F. T., \& Hertel, D. R. (2008). The past, present, and future of prairie potholes in the United States. $J$. Soil Water Cons., 63(3), 84A-87A. https://doi.org/10.2489/jswc.63.3.84A

Jones, C. N., Scott, D. T., Guth, C., Hester, E. T., \& Hession, W. C. (2015). Seasonal variation in floodplain biogeochemical processing in a restored headwater stream. Environ. Sci. Tech., 49(22), 13190-13198. https://doi.org/10.1021/acs.est.5b02426

Koerselman, W., Van Kerkhoven, M. B., \& Verhoeven, J. T. (1993). Release of inorganic N, P, and K in peat soils: Effect of temperature, water chemistry, and water level. Biogeochemistry, 20(2), 63-81. https://doi.org/10.1007/BF00004135

Kowalenko, C. G. (2005). Binding of inorganic sulphate and phosphate in humid-climate soils measured using column leaching, equilibration, and extraction methods. Canadian J. Soil Sci., 85(5), 599-610. https://doi.org/10.4141/S04-068

Kristensen, P., Sondergaard, M., \& Jeppesen, E. (1992). Resuspension in a shallow eutrophic lake. Hydrobiologia, 228(1), 101-109. https://doi.org/10.1007/BF00006481

Kröger, R., Lizotte, R. E., Shields Jr., F. D., \& Usborne, E. (2012). Inundation influences on bioavailability of phosphorus in managed wetland sediments in agricultural landscapes. $J$.
Environ. Qual., 41(2), 604-614.

https://doi.org/10.2134/jeq2011.0251

LaBaugh, J. W., Rosenberry, D. O., Mushet, D. M., Neff, B. P., Nelson, R. D., \& Euliss, N. H. (2018). Long-term changes in pond permanence, size, and salinity in prairie pothole region wetlands: The role of groundwater-pond interaction. J. Hydrol.: Regional Studies, 17, 1-23. https://doi.org/10.1016/j.ejrh.2018.03.003

Loeb, R., Lamers, L. P. M., \& Roelofs, J. G. M. (2008). Prediction of phosphorus mobilisation in inundated floodplain soils. Environ. Pollut., 156(2), 325-331. https://doi.org/10.1016/j.envpol.2008.02.006

Martin, A. R., Kaleita, A. L., \& Soupir, M. L. (2019). Inundation patterns of farmed prairie potholes with varying subsurface drainage. Trans. ASABE, 63(6), (in press).

Miller, B. A., Crumpton, W. G., \& van der Valk, A. G. (2009). Spatial distribution of historical wetland classes on the Des Moines Lobe, Iowa. Wetlands, 29(4), 1146-1152. https://doi.org/10.1672/08-158.1

NRCS. (1998). Wetland mapping conventions: NRCS Illinois 1998. Retrieved from https://efotg.sc.egov.usda.gov/references/Delete/2015-627/Archived_IL_Mapping_Conventions_150623.pdf

Pan, C. Z., Ma, L., \& Shangguan, Z. P. (2010). Effectiveness of grass strips in trapping suspended sediments from runoff. Earth Surface Proc. Landforms, 35(9), 1006-1013. https://doi.org/10.1002/esp.1997

Phipps, R. G., \& Crumpton, W. G. (1994). Factors affecting nitrogen loss in experimental wetlands with different hydrologic loads. Ecol. Eng., 3(4), 399-408. https://doi.org/10.1016/09258574(94)00009-3

Rice, E. W., \& Bridgewater, L. (Eds.). (2012). Standard methods for the examination of water and wastewater (22nd Ed.). Washington, DC: American Public Health Association.

Roth, J. L., \& Capel, P. D. (2012). The hydrology of a drained topographical depression within an agricultural field in northcentral Iowa. Trans. ASABE, 55(5), 1801-1814. https://doi.org/10.13031/2013.42367

Sawyer, J. E. (2018). Nitrogen use in Iowa corn production. Ames, IA: Iowa State University Extension and Outreach.

Schilling, K. E., Jacobson, P. J., Streeter, M. T., \& Jones, C. S. (2018). Groundwater hydrology and quality in drained wetlands of the Des Moines Lobe in Iowa. Wetlands, 38(2), 247-259. https://doi.org/10.1007/s13157-016-0825-9

Skopec, M., \& Evelsizer, V. (2018). Spring nutrient levels in drained wetlands of Iowa's prairie pothole region. Wetlands, 38(2), 261-273. https://doi.org/10.1007/s13157-017-0962-9

Smith, D. R., \& Livingston, S. J. (2013). Managing farmed closed depressional areas using blind inlets to minimize phosphorus and nitrogen losses. Soil Use Mgmt., 29(s1), 94-102. https://doi.org/10.1111/j.1475-2743.2012.00441.x

Sondergaard, M., Kristensen, P., \& Jeppesen, E. (1992). Phosphorus release from resuspended sediment in the shallow and windexposed Lake Arreso, Denmark. Hydrobiologia, 228(1), 91-99. https://doi.org/10.1007/BF00006480

Streeter, M. T., \& Schilling, K. E. (2015). A comparison of soil properties observed in farmed, restored, and natural closed depressions on the Des Moines Lobe of Iowa. Catena, 129, 3945. https://doi.org/10.1016/j.catena.2015.02.021

Tomer, M. D., James, D. E., \& Sandoval-Green, C. M. (2017). Agricultural conservation planning framework: 3. Land use and field boundary database development and structure. J. Environ. Qual., 46(3), 676-686. https://doi.org/10.2134/jeq2016.09.0363

Tomer, M. D., Moorman, T. B., Kovar, J. L., Cole, K. J., \& Nichols, D. J. (2016). Eleven years of runoff and phosphorus losses from two fields with and without manure application, Iowa, USA. 
Agric. Water Mgmt., 168, 104-111.

https://doi.org/10.1016/j.agwat.2016.01.011

Tomer, M. D., Wilson, C. G., Moorman, T. B., Cole, K. J., Heer, D., \& Isenhart, T. M. (2010). Source-pathway separation of multiple contaminants during a rainfall-runoff event in an artificially drained agricultural watershed. J. Environ. Qual., 39(3), 882-895. https://doi.org/10.2134/jeq2009.0289

Van Der Valk, A. G. (2005). Water-level fluctuations in North American prairie wetlands. Hydrobiologia, 539(1), 171-188. https://doi.org/10.1007/s10750-004-4866-3

Voldseth, R. A., Johnson, W. C., Gilmanov, T., Guntenspergen, G. R., \& Millett, B. V. (2007). Model estimation of land-use effects on water levels of northern prairie wetlands. Ecol. Appl., 17(2),
527-540. https://doi.org/10.1890/05-1195

Winter, T. C., \& Rosenberry, D. O. (1995). The interaction of groundwater with prairie pothole wetlands in the Cottonwood Lake area, east-central North Dakota, 1979-1990. Wetlands, 15(3), 193-211. https://doi.org/10.1007/BF03160700

Woltemade, C. J. (2000). Ability of restored wetlands to reduce nitrogen and phosphorus concentrations in agricultural drainage water. J. Soil Water Cons., 55(3), 303-309. Retrieved from http://www.jswconline.org/content/55/3/303.abstract

Zhu, B., Wang, T., Kuang, F. H., Luo, Z. X., Tang, J. L., \& Xu, T. P. (2009). Measurements of nitrate leaching from a hillslope cropland in the central Sichuan basin, China. SSSA J., 73(4), 1419-1426. https://doi.org/10.2136/sssaj2008.0259 